\title{
The political economy of food for your non-foodie friend in under 120 pages
}

\author{
Review by Aliza Tuttle, Portland State University*
}

Review of Can We Feed the World Without Destroying It? by Eric Holt-Giménez. (2019). Co-published by Polity Press \& Food First, Cambridge, UK, \& Medford, Massachusetts. Available in hardcover, paperback, and Kindle; 136 pages. Publisher's website: https:// foodfirst.org/can-we-feed-the-world-without-destroying-it/

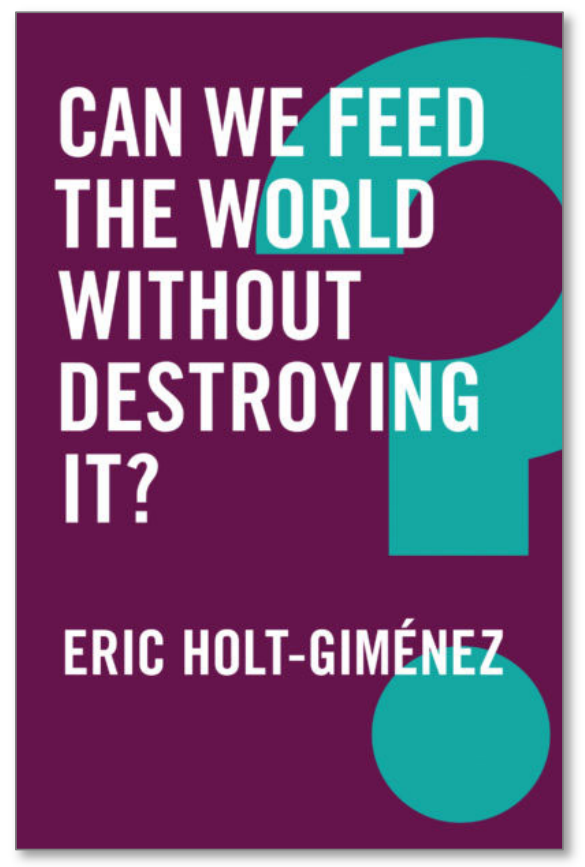

Submitted March 25, 2019 / Published online January 27, 2020

Citation: Tuttle, A. (2020). The political economy of food for your non-foodie friend in under 120 pages [Book review]. Journal of Agriculture, Food Systems, and Community Development, 9(2), 277-278. https://doi.org/10.5304/jafscd.2020.092.018

Copyright (C) 2020 by the Author. Published by the Lyson Center for Civic Agriculture and Food Systems. Open access under CC-BY license.

$\mathrm{E}$ ric Holt-Giménez, former executive director of Food First, adds the themes of agriculture, food policy, and food justice to Polity Press' Global Futures Series with Can We Feed The World Without Destroying It? Following previous publications in this series, this is a brief (118 pages) yet comprehensive introduction to the political economy of food written by one of the foremost authorities on food justice. Readers start at the food system's twisted capitalist roots and finish with hope in the transformative power of foodbased social movements, food sovereignty, and agroecology.

Holt-Giménez critically interrogates the question posed by the title, rhetorically answering

\footnotetext{
* Aliza Tuttle is an urban studies graduate student at Portland State University. She focuses on older adults and homelessness through the lens of the political economy of the food system. She can be reached at taliza@pdx.edu
}

simultaneously yes, no, and neither yes nor no. No, we cannot feed the world under the current system; but also yes, we can feed the world through systemic, fundamental changes to capitalism itself. This, he argues, "requires a critical understanding of capitalism" which, once attained, can be leveraged to "unleash the tremendous social power within the world's food systems not just to change the way we produce and consume our food, but also to transform society itself' (p. 9). This essay starts the reader on a whirlwind history of the capitalist food system, introduces failed historical fixes and impending climate catastrophes, and ends with a firm call to action.

Chapter One, "The Politics, Power, and Potential of Food," introduces the food system not as a bucolic scene in which farmers grow sustenance for the population, but as a market sector operating within capitalism, in which farmers produce a commodity to be sold on the market. Understood 
through the lenses of political economy and critical theory, the food system becomes simply a capitalist market sector-but with dire consequences for those without access to the market: starvation and death. The final paragraph of the introductory chapter is a call to action, the summary of a university course syllabus, and an introduction to a popculture TED talk: "The perpetual calls to end hunger, on the one hand, and to maintain our faith in technological progress, on the other, is a globalized form of cognitive dissonance that avoids addressing the contradiction of hunger in a world caught in the grips of overproduction and overconsumption" (p. 7).

Holt-Giménez leads the reader deeper into understanding hunger, overproduction, and overconsumption in Chapter Two, "Hunger in a World of Plenty." The chapter critiques the Food and Agriculture Organization of the United Nations (FAO)'s "slippery statistics" on global hunger, the global food price crisis, the green revolution, biofortification, food waste as a commodity, and food as a political commodity. He introduces the concepts of overproduction as endemic to capitalist food production and poverty as the cause of hunger.

This theme is explained using Friedmann and McMichael's food regime theory framework, augmented with Donella Meadows' systems thinking concepts in Chapter Three, "Food, Environment, and Systems Change." Holt-Giménez includes a lightning explanation of colonialism, Marxist theories of use value and exchange value, Neo-Marxist theories of metabolic rift, Ikerd's "technology treadmill," biodiversity, agriculture's contribution to climate change (including carbon sequestration), and a scathing critique of the "climate-smart trifecta" (p. 75). Here, Giménez introduces the concept of agroecology in response to the assumptions of the new agriculture. He closes the chapter by listing the upcoming tipping points, which are wide-ranging and intimidating. By now, the reader who is not actively outraged, exhausted, engaged, and worried is not reading carefully enough.

The concluding chapter's title asks the reader, "Who Can Feed the World Without Destroying It?" If the FAO is undercounting hungry people, corporations already monopolize production and distribution, and the food system is financialized and land speculative, the answer must be something structurally unique from all these forces. This is what Holt-Giménez leaves the reader with: a list of green techno-fixes and agroecology. The science, practice, and social movement that is agroecology is "anathema to capitalist agriculture" (p. 99), and represents the "no, but yes," to the titular question. The book ends by tying the restructuring of the food system to a concomitant global economic restructuring.

The middle-class, out-of-season eating, overconsumers reading this essay are the ones who can feed the world without destroying it—but only by "changing everything" (p. 118). Can We Feed The World Without Destroying It? is written for just this audience, albeit those already having a working knowledge of Meadows and Marx or else with access to the Internet and interest to look up terms such as "metabolic rift" and "negative feedback loops." The abbreviated length of the essay and the short chapters make this a versatile read for various audiences. A graduate course could begin by reading the entire essay, or the essay could supplement a section on agroecology (Chapter Four) or food regime theory (Chapter Two), using the readings referenced to round out concepts mentioned in passing in the text. The text could also be useful for current food scholars or political ecologists as a theory refresher. In general, the content is an abbreviated version of Holt-Giménez's earlier book, A Foodie's Guide to Capitalism (Holt-Giménez, 2017). The message in both books is similar: we are in for, and must create, a structural shift in how food is produced, distributed, and conceptualized ... or we won't be around to eat.

\section{Reference}

Holt-Giménez, E. (2017). A foodie’s guide to capitalism. New York: Monthly Review Press \& Food First Books. https://doi.org/10.2307/j.ctt1pwt8gg 